\title{
Effect of the Feed Additive Clinoptilolite (ZeoFeed) on Nutrient Metabolism and Production Performance of Laying Hens
}

\author{
Miroslav Macháček ${ }^{1}$, Vladimír Večerek ${ }^{1}$, Nora Mas², Pavel Suchý ${ }^{1}$, Eva Straková1, \\ Vlasta Šerman ${ }^{2}$, Ivan Herzig ${ }^{1}$ \\ ${ }^{1}$ Faculty of Veterinary Hygiene and Ecology, University of Veterinary and Pharmaceutical Science, Brno, \\ Czech Republic \\ ${ }^{2}$ Faculty of Veterinary Medicine, University of Zagreb, Croatia
}

Received December 1, 2009

Accepted March 8, 2010

\begin{abstract}
The aim of this study was to assess the effects of two levels of clinoptilolite administered in feed $(2 \%$ and $4 \%)$ on some selected performance indicators, metabolic utilization of basic nutrients and the health status of laying hens. The selected 24 Bovans Goldline hybrid laying hens were divided into three equal groups, two experimental groups (E1 and E2) and one control group (C). The laying hens were housed individually in cages with an automatic supply of drinking water, manual feeding, in a setting with controlled light and temperature regimens. Hens from individual groups were all fed a complete feed mix of the same composition and the only difference was in clinoptilolite supplementation: feed mixes for E1 and E2 groups contained $2 \%$ and $4 \%$ of clinoptilolite (commercial additive ZeoFeed) respectively, replacing the same amounts of wheat. The hens received feed mixes and drinking water ad libitum. During this 28-day experiment, feed consumption and the number and weight of eggs laid were monitored individually for each hen. At the end of the experiment, the balance test using the indicator method $\left(\mathrm{Cr}_{2} \mathrm{O}_{3}\right)$ was performed in all eight hens in each of the groups. The results of balance tests were then used to calculate the metabolic utilization of selected nutrients (nitrogen, fat, ash, nitrogen-free extracts, starch, gross energy, Ca, P). After the balance tests, blood samples for haematological and biochemical examinations were collected via puncture of the vena basilica. The addition of $2 \%$ clinoptilolite to feed mix resulted in a highly significant $(P \leq 0.01)$ increase in mean egg weight to $64.69 \mathrm{~g}$, but the addition of $4 \%$ clinoptilolite in group E2 resulted in a highly significant $(P \leq 0.01)$ decrease in mean egg weight to $62.20 \mathrm{~g}$ compared to the control (63.73 g). Moreover, daily feed mix consumption in group E1 decreased to 114 $\mathrm{g}$ per one laying hen/day compared to the controls (118 g per one laying hen/day). In group E2 (4\% clinoptilolite), daily consumption of feed mix increased compared with the controls to $124 \mathrm{~g}$. The $2 \%$ clinoptilolite supplementation of E1 group feed slightly increased metabolic utilization of fat, nitrogen-free extracts, starch and gross energy compared to group C. Results of haematological test of the hens' blood showed significant changes in haemoglobin, whose values in groups $\mathrm{C}$ and $\mathrm{E} 1$ were significantly higher $(P \leq 0.05)$ than in group E2. Differences in the values of the biochemical indicators monitored (total protein, glucose, cholesterol, triacylglycerols, calcium, phosphorus, magnesium and the AST enzyme) between group C and experimental groups E1 and E2 were not significant and remained within the range of reference values.
\end{abstract}

ZeoFeed, nutrient balance, biochemical profile, mineral profile, haematological profile

Feeds may be carriers of a number of contaminating exogenous substances that spread to food via food-producing animals and their products. For that reason, suitable approaches are being sought to prevent such substances from penetrating the animal organism and, subsequently, the food chain. There is a group of sorbents among feed additives that might be used to help resolve these problems; they are clinoptilolite-based natural zeolites. The crystal lattice of clinoptilolite offers a large internal sorption surface area. The size of its pores allows for selective ion exchange (Boranić 2000; Melenova et al. 2003), which is limited by the pore size. In terms of chemical composition, clinoptilolite is a hydrated aluminosilicate of alkaline metals and alkaline earth metals.

Address for correspondence:

MVDr. Miroslav Macháček

Department of Nutrition, Animal Husbandry and Animal Hygiene

Faculty of Veterinary Hygiene and Ecology

University of Veterinary and Pharmaceutical Sciences Brno

Palackého 1-3, 61242 Brno, Czech Republic
Phone: +420541562683

Fax: +420541562675

E-mail: machacekm @ vfu.cz

http://www.vfu.cz/acta-vet/actavet.htm 
In animal nutrition, clinoptilolites are used mainly to protect animals against mycotoxin intoxications (Skalicka and Makoova 1999; Skalicka et al. 2000; Rizzi et al. 2003; Modirsanei et al. 2004; Desheng et al. 2005), to eliminate heavy metals (Boranić 2000) and radionuclides (Poschl and Balas 1999; Vitorovic et al. 2002; Branislava and Gordana 2004), as well as to prevent digestive tract diseases, to improve utilization of feed nutrients, and to improve hygienic and sanitary conditions in animal housing facilities (Meisinger et al. 2001; Melenova et al. 2003). They have a positive effect on the production performance in pigs (Veldman and Aar 1997; Papaioannou et al. 2004) and in poultry (Amon et al. 1997; Olver 1997). Vogt (1991) found no significant improvement in production performance of laying hens associated with clinoptilolite supplementation. There was a slight improvement in the egg shell strength, reduction of the egg white height and improvement in yolk colour. Elliot and Edwards (1991) reported a positive effect of dietary natural clinoptilolite on feed utilization of broiler chickens.

In theory, sorbents may be assumed to have a negative effect on the digestibility and utilization of important nutrients such as minerals and vitamins. The majority of published papers, however, seem to testify to a positive effect of clinoptilolite-based sorbents on the mineral metabolism of animals, e.g. in pigs (Papaioannou et al. 2002) or in poultry (Elliot and Edwards 1991; Watkins and Southern 1991; Gezen et al. 2004; Desheng et al. 2005). The use of feed additives had no negative effect on biological efficiency of certain vitamins as demonstrated by Edwards et al. (1992) for vitamin D3 and by Gomonaj et al. (2000) for vitamin B1.

Data on the effect of various clinoptilolite levels on the metabolic utilization of basic nutrients are missing in the literature. Therefore, our aim was to investigate the effect of two different clinoptilolite levels $(2 \%$ and $4 \%)$ administered in the feed on the metabolic utilization of basic nutrients, laying hens' production performance and their health status assessed on the basis of haematological and biochemical profiles of their blood.

\section{Materials and Methods}

Animals and procedures

The experiments were conducted in accredited experimental barns of the Department of Nutrition, Animal Husbandry and Animal Hygiene at the Faculty of Veterinary Hygiene and Ecology of the University of Veterinary and Pharmaceutical Sciences in Brno and approved by the local Ethics Committee. The selected 24 Bovans Goldline hybrid laying hens were divided into three equal groups of 8 hens, i.e. two experimental groups (E1 and E2) and one control group (C). The laying hens were housed individually in cages with automatic watering, manual feeding, in a setting with controlled light and temperature regimens. The hens were all fed complete feed mixes with the same component composition and the only difference was their clinoptilolite supplementation, when feed mixes for E1 and E2 groups contained 2\% and 4\% of clinoptilolite (commercial additive ZeoFeed), respectively. The feed mixes and drinking water were provided ad libitum. The feed additive ZeoFeed contains at least $80 \%$ clinoptilolite as the active substance, and its moisture content is $6 \%$ maximum. Its other components include $62 \% \mathrm{SiO}_{2}, 14 \% \mathrm{Al}_{2} \mathrm{O}_{3}, 2.3 \% \mathrm{Fe}_{2} \mathrm{O}_{3}$ and 5. $\% \mathrm{CaO}$. ZeoFeed grain size is within the range of 0.2 to $0.5 \mathrm{~mm}$.

During the 28-day experiment, feed consumption and the number and weight of laid eggs were monitored individually for each hen. At the end of the experimental period, individual balance tests using the $\mathrm{Cr}_{2} \mathrm{O}_{3}$ indicator method were performed twice for 5 days on each of the eight hens in all three groups. The results of balance tests were then used to calculate metabolic utilization of selected nutrients (nitrogen, fat, ash, nitrogen-free extracts, starch, gross energy, Ca, P). After the balance tests, blood samples for haematological and biochemical examinations of the laying hens in the study were collected via puncture of the vena basilica. Haematological indicators, i.e. erythrocytes, haematocrit values, haemoglobin and leukocytes, were calculated in whole blood. Haematological examinations were performed using classical methods (Doubek et al. 2003). Biochemical indicators, such as total protein, glucose, cholesterol, triacylglycerols, aspartate aminotransferase (AST), Ca, P, $\mathrm{Mg}$, were determined in blood plasma after blood centrifugation. Biochemical indicators were determined using the biochemical analyzer Cobas EMira and commercial diagnostic kits, and mineral substances were determined using AAS. During the experiment, the health status of the laying hens was monitored daily. No clinical symptoms of disease or death were observed.

The results obtained were processed by mathematical-statistical methods using the statistical programme Unistat 5.6, mean values and their differences were assessed by multiple comparisons using Tukey-HSD test at levels of significance $P \leq 0.01$ and $P \leq 0.05$. 


\section{Results}

Production performance

The addition of $2 \%$ clinoptilolite to the feed mix resulted in a highly significant $(P \leq 0.01)$ increase in the mean egg weight to $64.69 \mathrm{~g}$ in group E1. The addition of $4 \%$ clinoptilolite in group E2, on the other hand, resulted in a highly significant $(P \leq 0.01)$ decrease in the mean egg weight to $62.20 \mathrm{~g}$ compared to the control $(63.73 \mathrm{~g})$. Moreover, daily feed mix consumption in group E1 decreased to $114 \mathrm{~g}$ per one laying hen/day compared to the controls (118 g per one laying hen/day). In group E2 (4\% clinoptilolite), the daily consumption of feed mix increased compared to the controls to $124 \mathrm{~g}$. The numbers of eggs laid were 197 (group C), 190 (group E1) and 177 (group E2).

Metabolic utilization of some selected nutrients

Compared to the control group C, the $2 \%$ clinoptilolite supplementation of E1 group feed slightly increased metabolic utilization of fat (92.15 vs. $93.63 \%)$, nitrogen-free extracts (89.03 vs. $90.68 \%)$, starch (97.01 vs. $97.82 \%)$ and gross energy ( 74.32 vs. $75.66 \%$ ) (Table 1). More efficient utilization of the above nutrients helped to increase gross energy utilization, which means that clinoptilolite supplementation also helped to

Table 1. Metabolic utilization of individual nutrients (\%) in the diet fed to laying hens $(\mathrm{x})$

\begin{tabular}{|l|c|c|c|}
\hline & $\mathrm{C}$ & $\mathrm{E} 12 \%$ & $\mathrm{E} 24 \%$ \\
\hline Nitrogen & 33.69 & 35.87 & 31.10 \\
\hline Fat & 92.15 & 93.63 & 91.96 \\
\hline $\begin{array}{l}\text { Nitrogen-free } \\
\text { extracts }\end{array}$ & 89.03 & 90.68 & 90.32 \\
\hline Starch & 97.01 & 97.82 & 97.77 \\
\hline Gross energy & 74.32 & 75.66 & 76.16 \\
\hline Ash & 32.91 & 21.27 & 26.01 \\
\hline Ca & 45.57 & 38.61 & 47.54 \\
\hline P & 21.21 & 47.54 & 23.28 \\
\hline
\end{tabular}
increase the feed metabolizable energy (ME). Higher metabolic utilization was also observed in nitrogen(33.69vs. 35.87\%)(Table 1). The higher (4\%) clinoptilolite content had a negative effect on most of the above indicators with the exception of starch and gross energy.

Metabolic utilization of mineral substances (Table 1) characterized by concentrations of ash, calcium (Ca) and phosphorus (P) was significantly reduced by the addition of $2 \%$ clinoptilolite (group E1). Interestingly, the addition of a higher amount (4\%) of clinoptilolite, on the other hand, increased calcium and phosphorus utilization.

It follows from the results of the conducted balance tests that the optimum level of clinoptilolite supplementation in feed mixes for laying hens is up to $2 \%$ clinoptilolite.

Results of haematological examinations

Compared to the control, lower mean values were found in the examined blood indicators (Table 2) particularly in group E2. The differences between mean values of the control group and the experimental groups were non-significant with the exception of the haemoglobin content, whose mean value in group E2 (4\% clinoptilolite) was significantly lower $(P \leq 0.05)$ compared

Table 2. Results of haematological examinations of laying hens $(\mathrm{n}=8)$ after continuous oral in-feed administration of clinoptilolite $(\mathrm{x} \pm \mathrm{SD})$

\begin{tabular}{|l|c|c|c|}
\hline & C & E1 2\% & E2 4\% \\
\hline Erythrocytes (T/1) & $1.80 \pm 0.232$ & $1.85 \pm 0.304$ & $1.72 \pm 0.262$ \\
\hline Haematocrit $(1 / 1)$ & $0.27 \pm 0.036$ & $0.26 \pm 0.026$ & $0.24 \pm 0.017$ \\
\hline Haemoglobin (g/l) & $78.56 \pm 6.389^{\mathrm{a}}$ & $79.40 \pm 4.479^{\mathrm{b}}$ & $70.38 \pm 7.761^{\mathrm{a}, \mathrm{b}}$ \\
\hline Leukocytes $(\mathrm{G} / \mathrm{l})$ & $20.71 \pm 4.419$ & $15.93 \pm 4.365$ & $19.0 \pm 6.530$ \\
\hline
\end{tabular}

a:a, b:b the means of values designated by the same letters are significant $(P \leq 0.05)$ to both control and group E1. The results indicate that higher in-feed clinoptilolite concentrations ( $4 \%$ in our case) may have a negative effect on haematopoiesis.

\section{Results of biochemical examinations}

No significant differences between biochemical indicators of blood plasma of laying hens from 
individual groups were found (Table 3). The experimental groups (E1 and E2) were found to have lower concentrations of total protein, cholesterol and triacylglycerol, but higher concentrations of glucose. Based on our results we assume that clinoptilolite administered at $2 \%$ and $4 \%$ levels will not significantly influence blood plasma composition.

\section{Discussion}

Zeolites (clinoptilolite) are used in animal nutrition for a number of beneficial effects they provide including better utilization of feed nutrients, positive effects on intestinal microflora and the mechanism of digestion, protection of animals against harmful effects of mycotoxins, stimulation of liver detoxification processes, elimination of heavy metals and radioactive elements.

Because of their properties, in-feed zeolites participate in many biochemical processes including exchange, adsorption, catalysis and dehydration-rehydration (Mumpton 1999). It has been demonstrated in a number of studies that the inclusion of zeolites in animal diets improves weight gains and feed conversion in broilers (Fethiere et al. 1994; Olver 1997), egg production in laying hens (Olver 1997), and has a positive effect of egg weight and their physical properties (Tserveni-Gousi et al. 1997). The extent of positive effects on performance depends on the type of zeolite used, its purity, physical and chemical characteristics and its concentration in diet.

Clinoptilolites have been demonstrated to have a positive effect on the metabolic utilization of nitrogen in poultry and pigs. This suggests that it may be possible to reduce the concentrations of nitrogenous substances in feed rations without adversely affecting production performance of animals. An important benefit of their use is the ability of clinoptilolites to bind ammonia, which reduces nitrogen excretion in faeces and thus also lowers its concentrations in livestock barns and in the environment (Amon et al. 1997; Meisinger et al. 2001; Melenova et al. 2003).

Research into application of these substances in laying hens is a specific area (WuHaan et al. 2007; Olver 1997; Rabon et al. 1991; Roland et al. 1993; Roland et al. 1985). Nys (1999) noted that synthetic zeolites with a high cation exchange capacity slightly improve egg shell quality because they form complexes with $\mathrm{Ca}$. In terms of specific weight, a positive effect of zeolites on eggshell quality was demonstrated in a majority of studies. Positive effects were observed in particular when dietary $\mathrm{Ca}$ was at a marginal level of $2.75 \%$ (Roland et al. 1985) and at the time of elevated environmental temperatures (Keshavarz and McCormick 1991). In addition to their positive effects on production performance in animals, in-feed zeolites are effective in enhancing prevention of some diseases and improving the health status. Mechanisms of enhancing properties of dietary zeolite on production performance of animals were summarized by Papaioannou et al. (2005).

The results presented in this paper corroborate some literary data and complement others. The most important finding is the positive effect of lower clinoptilolite concentration on metabolic utilization of nutrients, production performance indicators (egg weight), and lowering of daily feed consumption. This may be explained by the above-mentioned range of positive effects of zeolites. Our results show that clinoptilolite is a useful feed additive. Concentrations in rations for laying hens up to $2 \%$ are considered optimal. Higher concentrations present certain risks in terms of laying hens' production performance and possible negative effects on haemopoiesis. Indirect effects of clinoptilolite should also be considered: at higher doses and long-term administration it may affect the utilization of biologically active substances such as vitamins, trace elements and other specific-action substances and thus influence nutrient metabolism indicators. To verify this hypothesis, further experiments will have to be conducted. 


\section{Vliv krmného aditiva klinoptilolitu (ZeoFeed) na metabolismus živin a užitkovost nosnic}

Cílem práce bylo posoudit vliv dvou hladin klinoptilolitu podávaného v krmivu (2 a 4\%) na vybrané ukazatele užitkovosti, metabolizovatelnost základních živin a zdravotní stav užitkových nosnic. Vybraných 24 nosnic, hybrida Bovans Goldline, bylo rozděleno do tř́ vyrovnaných skupin, kontrolní (C) a dvou pokusných (E1 a E2). Nosnice byly chovány individuálně v klecové technologii s automatickým napájením, ručním krmením, $\mathrm{v}$ prostředí s řízeným světelným a teplotním režimem. Nosnice jednotlivých skupin přijímaly kompletní krmnou směs stejného složení s tím rozdílem, že krmná směs určená pro skupinu E1 obsahovala 2\% a pro skupinu E2 4\% klinoptilolitu (komerční aditivum ZeoFeed), náhradou za stejný podíl pšenice. Krmné směsi a pitnou vodu přijímaly nosnice ad libitum. Spotřeba krmiva, počet a hmotnost snesených vajec byla v prủběhu experimentu, který trval 28 dnů, sledována individuálně u každé nosnice. Na konci pokusného období byla u osmi nosnic každé skupiny provedena bilanční zkouška indikátorovou metodou $\left(\mathrm{Cr}_{2} \mathrm{O}_{3}\right)$. Z výsledků bilancí byla vypočítána metabolizovatelnost vybraných živin (dusík, tuk, popel, bezdusíkaté látky výtažkové, škrob, brutto energie, $\mathrm{Ca}, \mathrm{P}$ ). Po ukončení bilanční zkoušky byla u sledovaných nosnic odebrána krev punkcí vena basilica, pro hematologická a biochemická vyšetření. Podávání $2 \%$ klinoptilolitu v krmné směsi vedlo u skupiny E1 k vysoce významnému $(\mathrm{P} \leq 0.01)$ zvýšení průměrné hmotnosti vajec na $64.69 \mathrm{~g}$ a naopak u skupiny E2 k vysoce významnému $(\mathrm{P} \leq 0.01)$ snížení průměrné hmotnosti vajec na $62.20 \mathrm{~g}$, oproti kontrole $(63.73 \mathrm{~g})$, při snížené denní spotřebě krmné směsi u skupiny E1 na 114 g oproti kontrole $118 \mathrm{~g}$ na 1 nosnici/den. U skupiny E2 (4\% klinoptilolitu) se denní spotřeba krmné směsi oproti kontrole zvýšila na $124 \mathrm{~g}$. Př́idavek $2 \%$ klinoptilolitu v krmivu skupiny E1 mírně zvýšil, oproti skupině C, metabolizovatelnost tuku, bezdusíkatých látek výtažkových, škrobu i brutto energie. Výsledky hematologických vyšetření krve nosnic prokázaly statisticky významné změny u hemoglobinu, jehož hodnoty byly u skupiny $\mathrm{C}$ a E1 statisticky významně vyšší $(\mathrm{P} \leq 0.05)$ než hodnota u skupiny E2. U sledovaných biochemických ukazatelů (celkový protein, glukóza, cholesterol, triacylglyceroly, vápník, fosfor, hořč́k a enzym AST) nebyly hodnoty mezi skupinou C a pokusnými skupinami E1 a E2 statisticky významně rozdílné a pohybovaly se v rámci referenčních hodnot.

\section{Acknowledgements}

Financial support from the Ministry of Education, Youth, and Sports of the Czech Republic (Grant No MSMT 6215712402) is gratefully acknowledged.

\section{References}

Amon M, Dobeic M, Sneath RW, Philips VR, Misselbrook TH, Pain BF 1997: A farm-scale study on the use of clinoptilolite zeolite and De-Odorase ${ }^{\circledR}$ for reducing odour and ammonia emissions from broiler houses. Bioresource Technology 61: 229-237

Boranić M 2000: What a physician should know about zeolites. Liječnički Vjestnik 122: 292-298

Branislava S, Gordana V 2004: The efficiency of the radiocesium binders-AFCF and clinoptilolite in broiler chickens exposed to alimentary contamination with Cs-137. Acta Vet Beograd 54: 437-446

Desheng Q, Fan L, Yanhu Y, Niya Z 2005: Adsorption of aflatoxin B-1 on montmorillonite. Poultry Sci 84: 959-961

Doubek J. et al. 2003: Veterinární hematologie. 1. vydání, Novico a.s. ISBN 80-86542-02-5. $464 \mathrm{~s}$

Edwards HM, Elliot MA, Sooncharernying S 1992: Effect of dietary calcium on tibial dyschondroplasia interaction with light, cholecalciferol, 1,25-dihydroxycholecalciferol, protein, and synthetic zeolite. Poultry Sci 71: 2041-2055

Elliot MA, Edwards HM 1991: Comparison of the effects of synthetic and natural zeolite on laying hen and broiler chicken performance. Poultry Sci 70: $2115-2130$

Fethiere R, Miles RD, Harms RH 1994: The utilization of sodium in sodium zeolite A by broilers. Poultry Sci 73: $118-121$

Gezen SS, Eren M, Deniz G 2004: The effect of zeolite on broiler performance. Indian Vet J 81: 411-415

Gomonaj V, Gomonaj P, Golub N, Szekeresh K, Charmas B, Leboda R 2000: Compatible adsorption of strontium and zinc ions as well as vitamins on zeolites. Adsorption Science and Technology 18: 295-306 
Keshavarz K, McCormick CC 1991: Effect of sodium aluminosilicate, oyster shell, and their combinations on acid-base-balance and eggshell quality. Poultry Sci 70: 313-325

Meisinger JJ, Lefcourt AM, Van Kessel JA, Wilkerson V 2001: Managing ammonia emissions from dairy cows by amending slurry alum or zeolite or by diet modification. Scientific World Journal 27, Suppl 1: 860-865

Melenová L, Ciahotny K, Jirglová H, Kusa H, Růžek P 2003: Removal of ammonia from waste gas by means of adsorption on zeolites and their subsequent use in agriculture (in Czech). Chemické Listy 97: 562-568

Modirsanei M, Khosravi AR, Kiaei SMM, Fard MHB, Gharagozloo MJ, Khazraeinia P 2004: Efficacy of dietary natural zeolite and Saccharomyces cerevisiae in counteracting aflatoxicosis in broiler chicks. J Appl Anim Res 26: $39-44$

Mumpton FA 1999: La roca magica: Uses of natural zeolites in agriculture and industry. Proceedings of the National Academy of Sciences of the United States of America 96: 3463-3470

Nys Y 1999: Nutritional factors affecting eggshell quality. Czech J Anim Sci 44: 135-143

Olver MD 1997: Effect of feeding clinoptilolite (zeolite) on the performance of three strains of laying hens. Br Poultry Sci 38: 220-222

Papaioannou D, Katsoulos PD, Panousis N, Karatzias H 2005: The role of natural and synthetic zeolites as feed additives on the prevention and/or the treatment of certain farm animal diseases: A review. Microporous and Mesoporous Material 84: 161-170

Papaioannou DS, Kyriakis CS, Alexopoulos C, Tzika ED, Polizopoulou ZS, Kyriakis SC 2004: A field study on the effect of dietary use of a clinoptilolite-rich tuff, alone or in combination with certain antimicrobials on the health status and performance of weaned, growing and finishing pigs. Res Vet Sci 76: 19-29

Papaioannou DS, Kyriakis SC, Papasteriadis A, Roumbies N, Yannakopoulos A, Alexopoulos C 2002: Effect of in-feed inclusion of a natural zeolite (clinoptilolite) on certain vitamin, macro and trace element concentrations in the blood, liver and kidney tissues of sows. Res Vet Sci 72: 61-68

Poschl M, Balas J 1999: Reduction of radiocaesium transfer to broiler chicken meat by a clinoptilolite modified with hexacyanoferrate. Radiation and Environmental Biophysics 38: 117-124

Rabon HW, Roland DA, Bryant M, Barnes DG, Laurent SM 1991: Influence of sodium elite-A with and without pullet-sized limestone or oyster shell on eggshell quality. Poultry Sci 70: 1943-1947

Rizzi L, Simioli M, Roncada P, Zaghini A 2003: Aflatoxin B1 and clinoptilolite in feed for laying hens: Effects on egg quality, mycotoxin residues in livers, and hepatic mixed-function oxygenase activities. J Food Protection 66: $860-865$

Roland DA, Laurent SM, Orloff HD 1985: Shell quality as influenced by zeolite with high ion-exchange capability. Poultry Sci 64: 1177-1187

Roland DA, Rabon HW, Rao KS, Smith RC, Miller JW, Barnes DG, Laureat SM 1993: Evidence for absorption of silicon and aluminium by hens fed sodium zeolite-A. Poultry Sci 72: 447-455

Skalicka M, Jaklova Z 1999: Elimination of aflatoxin B-1 in broiler chicks by clinoptilolite. Bulletin of the Veterinary Institute in Pulawy 43: 211-219

Skalicka M, Jaklova Z, Korenekova B 2000: The influence of aflatoxin B-1 on activity of alkaline phosphatase and body weight of broiler chicks. Trace Elements and Electrolytes 17: 146-142

Tserveni-Gousi AS, Yannakopoulos AL, Katsaounis NK, Filippidis A, Kassoli-Fournaraki A 1997: Some interior egg characteristics as influenced by addition of Greek clinoptilolitic rock material in the hen diet. Archiv fur Geflugelkunde 61: 291-296

Veldman A, Van der Aar PJ 1997: Effects of dietary inclusion of a natural clinoptilolite (Mannelite TM) on piglet performance. Agribiological Research - Zeitschrift fur Agrarbiologie Agrikulturchemie Okologie 50: 289-294

Vitorovic G, Slavata B, Stolic K, Mladenovic V, Vitorovic D 2002: The effect of clinoptilolite on Cs-137 binding in broiler chickens. Agricultural and Food Science in Finland 11: 137-141

Vogt H 1991: The effect of clinoptilolite in laying hen rations. Landbauforschung Volkenrode 41: 146 -150

Watkins KL, Southern LL 1991: Effect of dietary-sodium zeolite-A and graded-levels of calcium on growth, plasma, and tibia characteristics of chicks. Poultry Sci 70: 2295-2303

Wu-Haan W, Powers WJ, Angel CR, Hale CE, Applegate TJ 2007: Effect of an acidifying diet combined with zeolite and slight protein reduction on air emissions from laying hens of different agents. Poultry Sci 86: 182-190 